Center for

Higher Education

Policy Studies

\title{
Involving universities in regional upgrading in the periphery
}

\author{
Lessons from Northern Europe
}

\author{
CHEPS WORKING PAPER 10/2015 \\ Paul Benneworth. CHEPS (University of Twente) \\ p.benneworth@utwente.nl
}

Rómulo Pinheiro. Department of Political Science \& Management (University of Agder)

romulo.m.pinheiro@uia.no

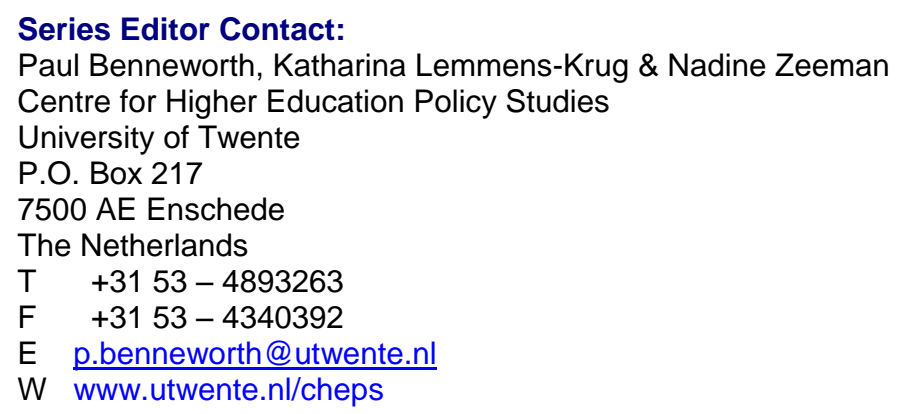




\section{Abstract}

This chapter presents and discusses two cases of regional upgrading involving publicrun universities in two Northern European countries, Norway and the Netherlands. More specifically, it illuminates how academic groups associated with the field of medicine took pro-active steps to establish and further develop regional coalitions which, over time, have resulted in situated learning. The focus on processes of university-regional engagement and mutual satisfaction in a context where universities are pressured to be globally excellent allow lessons to be drawn for regions in Southern Europe. Subtle transfer is nevertheless required to account for universities' autonomies and organisational capacity to embed engagement at the institutional level.

Keywords: Higher education, regional development, universities, Northern Europe, local relevance and global excellence, tensions. 


\section{Table of Contents}

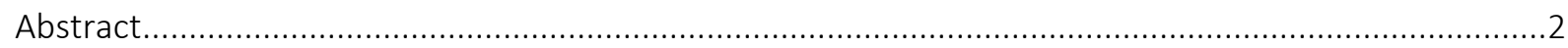

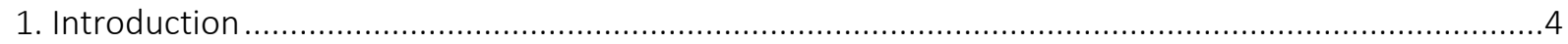

2. The regional conundrum - tying universities to their regions ...................................................

3. The logic of universities' regional engagement \& Upgrading activities ......................................

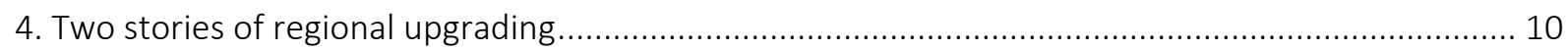

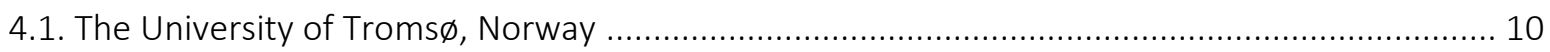

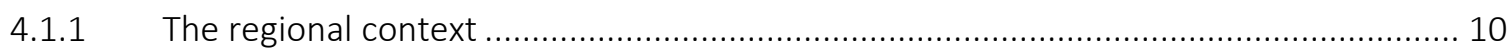

4.1.2. UiT: the knowledge hub for the 'High North' .................................................... 11

4.2.3 Situated learning: the case of community medicine ............................................ 12

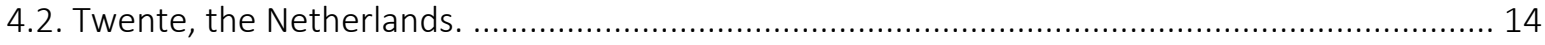

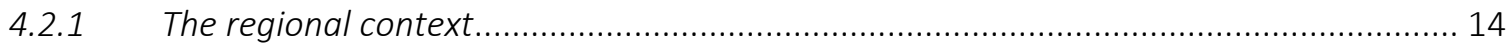

4.2.2 The University of Twente as a key knowledge economy actor .............................. 15

4.2.3 Situated learning: the case of technical medicine ........................................... 16

5. The reality of universities and regional upgrading in the northern periphery ............................ 17

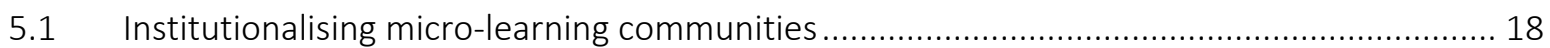

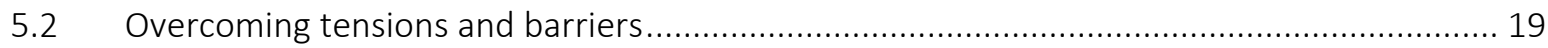

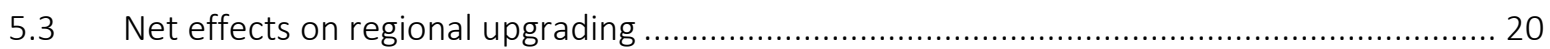

6. Lessons for university-regional engagement in southern Europe ............................................ 21

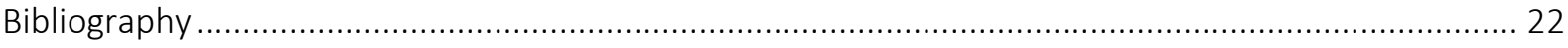




\section{Introduction}

The volume for which this chapter has been prepared is intimately concerned with regional upgrading processes in southern Europe. Regional policy has latterly placed increasing emphasis being lain on stimulating regional coalitions of innovations to engage in entrepreneurial discovery processes and developing what are called 'smart specialisation strategies' (McCann \& Ortega Argiles, 2013). This approach builds on a much longer tradition of supporting regional upgrading by encouraging regional partnerships to develop technology plans (Morgan, 1992) and later, innovation strategies (Morgan \& Nauwelaers, 2002). Universities have become central to the arguments that are made about regional upgrading, as critical elements of regional innovation systems, generating knowledge within international networks that local actors are able to exploit, generating exports, raising productivity and competitiveness and ultimately social welfare (Cooke, 2005).

A huge amount of research has been undertaken to explore the ways in which universities work with their regions to help create these unique competitive advantages. This can be both directly in economic terms (cf. Hermansson et al., 2013) but also indirectly, by contributing to social, environmental, and cultural development (Charles \& Benneworth, 2002; OECD, 2007), social justice (Benneworth, 2013) and regional governance (Gunasekara, 2006). Their staff and their associated activities can help fill structural gaps in regional innovation systems, build social capital and unleash innovative potential (Hansen et al., 2004; Kallio et al., 2011). Universities can play leadership roles in these coalitions that develop regional innovation strategies (Sotarauta et al., 2012), and provide for a stewardship of place through their civic engagement building knowledge cities (Goddard \& Vallance, 2013). There has likewise been a flourishing of stories told about the vitality of universities to regional economic development, along with a set of recipes for what regions ought to do to engage with their regions based on a regional higher education partnership mapping the regional system and cleverly designing appropriate interventions (Goddard, 2011).

In this chapter, we are concerned here with understanding what universities can offer to regional development in the southern periphery, where the environments for regional engagement may be quite different from the contexts within which these more generalistic policy lessons are developed. Certainly, we are mindful here of the need to avoid making simplistic prescriptions and recipes for delivering regional upgrading that in reality involve inevitably fruitless attempts to mimic and chase after past successes (cf. Hospers 2006). However, we nevertheless argue that one area where southern universities and regions can learn from their 'northern neighbours' is in the internal university processes that are common across institutions and not dependent upon or inhibited by particularly munificent or sparse environments for regional innovation encouraging university behaviour.

The common conundrum for universities with which we are here concerned is the issue of 'situated learning', where universities attempt to develop courses relevant to and 
supportive of regional development trajectories. University knowledge is validated based on its generalisability and transferability. Developing and teaching contextspecific, unique knowledge always raises a question of whether this is 'higher' education, or merely vocational training. This echoes a kind of Bildung/ Ausbildung or Blue Skies vs Applied tension that recurs whenever universities engage with society. We argue that a common pressure on universities in the southern as well as northern periphery is to be globally excellent and pursue internal visibility. They may therefore regard regional engagement as being detrimental to this mission, and it is this tension with which this chapter is fundamentally concerned, and it is a tension facing universities as much on the southern as the northern periphery. In this chapter, we therefore pose the question of what lessons can southern Europe learn regarding improving university-regional engagement activity by better aligning universities' institutional interests with those of their host territories.

\section{The regional conundrum - tying universities to their regions}

To better understand how universities can contribute to regional development and work with regional actors across the public and private sectors, we argue that it is necessary to understand what universities are for and about the ways they are organised internally in/around their core activities of teaching and research. There is an overly simplistic elision between the observation that universities can under some circumstances work with regions in ways that are beneficial, and the normative statement that universities should work to contribute to regional upgrading. As Stefan Collini (2011) noted, if the key to being a successful societal institution was doing what funders immediately demanded, then technical colleges would be the model to which liberal arts universities aspired, and not vice versa. Universities as institutional forms have evolved over almost a millennium precisely because they have found ways to reinvent their societal usefulness whilst allowing them to retain a degree of resistance to such outside pressures (Bender, 1988).

A key dimension of their resilience as institutions comes from the fact that they are highly flexible and adaptive (Karlsen and Pritchard, 2013). This resilience and adaptive capacity derives, to a large degree, from the fact that they are formed from an overlapping kaleidoscope of different communities. These communities (e.g. staff in a department, students on a particular year of a course) all share the common characteristic of being interested in knowledge production and circulation, but each community will have their own interests and trajectories. The institution of university is formed from the aggregate of these communities that are held together in a way that may be regarded as being "loosely coupled" (Reponen, 1999). Their core staff, academics, have evolved into distinctive disciplinary 'tribes' with their own approaches to creating, evaluating, judging, circulating and rejecting knowledge (Becher \& Trowler, 2001). Attempts to impose top-down, 'strategic' forms of management in the new public 
management vein (cf. Kickert, 1995) have had to confront new problems in creating empowering environments for academics. A particular problem for top-down management are the deep-seated problems in developing fair metrics of university regional engagement that are capable of providing more than cursory insights into individual institutional performance improvement (Van Vught \& Westerheijden et al., 2011; Charles \& Wilson, 2012).

There is huge variability in how seriously universities take the idea of a regional mission, not just between different kinds of institution (polytechnic versus university, technical vs broad, rural vs urban, pure vs applied disciplines), but also related to their specific history, culture and organisational structure. And, there is also a clear risk of portraying the university of loosely coupled communities as a single coherent institution where strategic-decision making is enough to encourage these diverse communities and tribes to follow a common direction of travel. What is common to those universities that take regional engagement seriously is that this (third) mission tends to fit with the interests, goals and desires of the various communities and 'tribes' within the university (cf. Pinheiro, 2012b).

In this chapter, we therefore argue that understanding how universities can contribute to regional upgrading means to grasp how universities - and their various communities and tribes - can benefit from regional upgrading. For the university as a para-institution (i.e. the organisation is less significant as an institution than the sub-institutions, the communities of which it is composed), these effects come in terms of developing a more regional-engagement friendly set of formal structures as well as developing informal norms, practices, networks and institutions that support and facilitate regional engagement. For the region, this involves creating activities where there are more shared agendas, collaboration, clustering and evolution with regional partners, and the absence of strategic disagreement, competition, fragmentation and lock-in within other regional actors.

But at the same time, it is important to stress that universities do not have a single set of interests, logics or norms arising from their loosely coupled nature (Olson, 2007). Although the formal institution may have a single strategic vision, mission and goals, that can be at odds with a plurality of purposes and identities of different kinds of scholars and professionals derived from their 'tribes'. There are a set of material dependencies that universities face, as all universities are dependent on sponsors for survival, but at the same time need to ensure that sponsor financial dependency does not lead to a loss of their independence of inquiry upon which ultimately all their social benefits are created. Universities likewise need in some areas to take cohesive and united action, for example around estates development, to hold these tribes together, while at the same time ensuring that this does not stifle the individual autonomy upon which their creativity and utility is built. Universities as institutions may have a long set of histories and traditions upon which they are founded, but the fact that everyone in the 
university is engaged in progress means that managing institutional self-renewal becomes a critical task.

At the same time, in recognising the complexity of universities as institutions, it is important to acknowledge Lagendijk \& Oinas's (2005) argument that regional economies are themselves complex, and co-ordinating activity between actors is a difficult process riven with tensions. Pinheiro et al. (2015) also point to four tensions within regions that affect universities' capacity to regionally engage. Firstly, regions are host to many actors with competing demands and interests - even municipalities may not all have a common 'regional' interest but seek preferential outcomes for their locality. Under such circumstances, engagement with some groups by a university may alienate and generate resistance from others.

Secondly, although the literature puts an emphasis on trust and social capital, innovation processes are commercially-laden processes where competition and secrecy can be critical, and firms may seek to limit the knowledge-overspill benefits that the region gets from them (Christopherson \& Clark, 2007). University efforts to profit from their knowledge often involve its privatisation and codification, which may reduce opportunities for regional collaboration and inhibit regional overspill effects.

Thirdly, firms may be more influenced by what is happening in their wider technological innovation system than in the local environment, particularly for emerging technologies (Bergek et al. 2008) and, as a result, construct multi-local valorisation systems where activities in other regions are more determining. It makes more sense for universities with particular technological specialities to engage with the key actors in that specific technological innovation system than trying to engage in areas where those underlying expertises are lacking.

Finally, and particularly important in the context of regional upgrading, are the tensions around breaking path-dependencies, which are associated with strong local networks that lock a region into old behaviours, and therefore resist upgrading (Hassink, 2005). There can be a range of potential pathways to regional upgrading that involve universities stimulating these locked-in regional networks to identify and pursue new trajectories, but these can challenge the existence of some of the companies, and reduce the willingness of partners to co-operate around new technological areas.

Of course, the widespread fact that universities do work with regions in upgrading activities indicates that these barriers are not insurmountable. Our contribution in this chapter comes in identifying these processual steps that universities can take - whether in the north or south of Europe - to address these pressures that arise when engaging with regional partners. As these problems are less specific to regional context and more to the particular institutional form of universities, we argue they are more transferrable across national and regional contexts. Therefore, as a first step to develop some 
meaningful lessons for southern Europe, we now develop a conceptual framework for understanding how universities - as complex actors - negotiate these tensions, and create formal structures and informal cultures that allow them to meaningfully contribute to and benefit from regional engagement activities.

\section{The logic of universities' regional engagement \& Upgrading activities}

Benneworth (2013) has argued that university engagement missions are at their most stable when they progress from being based on a sense of corporate responsibility, what he calls 'munificent beneficence', to being embedded in universities' core structures, routines and values. There is a dialectic element to this: universities have a series of tangible activities that have interdependencies with external communities, and the need to interact productively with external stakeholders influences the intangible norms and routines of universities' internal communities. Those intangible university elements, in turn, represent a form of social capital that contributes to the success of the regional element, also because they are not easily captured or appropriated by others. Earlier studies have identified three main types of communities with which universities typically engage; those that are geographically proximate to them ('regional communities'), ethically proximate to them (institutions with a religious background working with charities) or with a similar kind of mission (technology universities working with businesses) (Benneworth \& Osborne, 2014; CERI 1982). The interplay between these internal, intangible institutions and external, tangible activities, can act to transform the university into becoming an engaged institution (cf. Goddard \& Vallance, 2012 for how this happens with regional communities).

That being said, engagement is not a simple process to achieve through the creation of a regional higher education partnership or a strategic management interface within the university. This happens when communities within the university develop connections with external communities, and these connections ultimately create a mutual interdependence between university and regional interests at a strategic level. The art of strategic management in this case is in creating synergies and a supportive environment for these various communities. But, at the same time, tensions can arise because what these different communities do not have is a shared corporate sense of interest; their shared interests are emergent and related to individual knowledge exchanges around core processes of teaching and research, involving the creation, circulation, fusion, progression and withdrawal of knowledge. By looking at these underlying processes, critical insights into how these mutual interdependencies can be built (and managed) is greatly assisted. As argued above, lessons to be learned are not context dependent, but applicable wherever there are universities who feel themselves caught between regional relevance and global excellence (Perry, 2012).

We, therefore, look at the dynamics of these boundary spanning communities involving both universities and regional actors in knowledge processes. A Above it was described 
that, in successful cases of engagement, university staff come together with external partners, work jointly on issues of common interest and develop shared norms (and sometimes a shared identity, e.g. in the form of a 'regional coalition'), and, ultimately, align their long-term strategic interests, creating social capital. The processes by which this takes place can be considered to be social and situated learning processes, and understood through frameworks such as communities or networks of practices (cf. Benner, 2003; Amin \& Roberts, 2008). These social learning processes involve a group of core actors coming together into a social 'learning space' to exchange different kinds of knowledge; which may be a virtual environment (Roberts, 2014). Through this activity, engaged actors create situated forms of knowledge within the local group. Through their participation in other knowledge communities, local and global, the 'situated knowledge' that was initially created within a given local context is able to flow through these networks to other partners who can then use it to solve their own (local) problems.

Gertner et al. (2011) provide a good example of this through an analysis of the 'Knowledge Transfer Partnership' (KTP) programme undertaken by Strathclyde University in the UK, a detailed knowledge exchange between university and firms involving individuals employed by the university but placed in the firm. They show how the programme operates through individuals who are 'boundary-spanners' with multimemberships of university learning communities (Mutch, 2003). The core of the learning community is the $\operatorname{KTP}(-\mathrm{s})$, and at the periphery stand the university academic and the firm R\&D manager, who are at the core of their own communities of practices concerned with academic research and innovation, respectively. Knowledge circulates within these three communities around the pivot of the KTPs, with the effect that academic research and firm innovation are mutually enriched, hence creating a shared strategic interest between university and regional firm.

Notwithstanding, these individual learning communities are exposed to the various tensions outlined above. Academics participating in schemes such as the KTP must balance: commercial interests with academic autonomy; their scholarly needs with the university's commercial interests; consultancy time with teaching and research time; in addition to maintaining their place in university structures. Likewise, firms engaging with universities are situated within their own corporate hierarchies, being active in international innovation networks that may ultimately be more important to their decision-making. They often worry about 'leakage' of ideas to competitors via the university, and try to ensure that they can profit commercially from innovation expenditure. The existence of the scheme shows that these tensions can be overcome at a micro-scale, on a case-wise basis. But the more important issue here is how does this translate up from the micro-level (of individual interaction), to the meso-level (of university and region working together), creating situated knowledge that drives 
regional upgrading against the backdrop of given these prevailing meso-tensions within universities and regions. This process is depicted in figure 1 below.

\section{[FIGURE 1 GOES ABOUT HERE]}

\section{Two stories of regional upgrading}

Our key concern here is on how these situated learning environments do two things, both anchoring engagement within the university (stimulating university success), but also creating situated knowledge communities that make new kinds of knowledge available for regional partners (regional upgrading). We focus not only on the individual situated learning environments, but also consider how these affect both the university and the regional actors. In this chapter, we therefore explore through two case studies: (i) how these micro-learning communities were institutionalised and embedded in universities and regions; (ii) the tensions they faced, and the barriers they overcame; and (iii) the effect that this ultimately had on regional upgrading. We thereby identify potential barriers regions may face in using universities to contribute to their economic upgrading, and reflect on the consequences that this may have for Southern European regions.In light of this, the primary focus of our analysis lies on the role played by selected case universities (each with a specific institutional profile) in Northern Europe (one in Norway and one in the Netherlands) in supporting the regional upgrading of their respective regions. More specifically, we investigate how academic groups associated with the field of medicine played a critical role in the establishment of 'situated learning communities' that were locally-embedded, yet globally connected to other centres of knowledge and expertise, thus providing a gateway to/from the region to the outside world. In this section, we set out the events that took place, and in section 5 , we explore these events more critically through the lens of universities as a loose coalition of loosely coupled communities. This enables us, in the concluding section, to draw a set of broad or universal institutional lessons independent of regional contextual specificities thereby having a greater relevance for universities throughout southern Europe.

\subsection{The University of Tromsø, Norway}

\subsubsection{The regional context}

Northern Norway covers a geographic area of approximately 113 thousand square kilometres, a third of the total, and a combined population of about 460 thousand inhabitants ( $9.6 \%$ of the total). Historically, fishery and farming dominated the life of the region. In the last couple of decades substantial changes have occurred in the three Northern counties (NUTS-3, counties 18-20 in figure 2 below). Nordland became a stronghold for industrial activity. Troms experienced the steady rise of a tertiary sector. Tourism and energy exploration have become important income sources for Finnmark. The region is characterised by its vast public sector infrastructure, the largest in the country in per capita figures. The regional economy is dominated by small, often family- 
owned, businesses of less than ten employees. No large corporations are headquartered in the region, albeit the presence of local branches or subsidiaries for major domestic and international players across sectors like manufacturing, construction, energy/oil, etc.

One of the biggest economic challenges facing Northern Norway pertains to the structural changes that have occurred within the fishery industry in the last two decades. Deregulation and the rise of a global fishery sector dominated by large scale, highly efficient fleet operators have had a catastrophic effect on both the size and competitiveness of small, local businesses. The recent global financial crisis has resulted in over-pricing and the lack of demand for local products. There is a gradual move from low skilled industries based on abundant natural resources like fish towards highly profitable knowledge-based sectors such as marine bio-prospecting. As far as regional development policy is concerned, the most significant event in recent years pertains to an ambitious government-led initiative (since 2006) targeting the region; the so-called "strategy for the High North", an area encompassing the Artic and Barents Sea (figure 4). It involves a total of 14 Ministries and spans across a broad portfolio of strategic areas from foreign policy to knowledge generation and competence building to environment to indigenous people/culture, etc. (Pinheiro, 2012a).

Figures 2 \& 3: Norway's (19) Counties \& (5) Administrative Regions
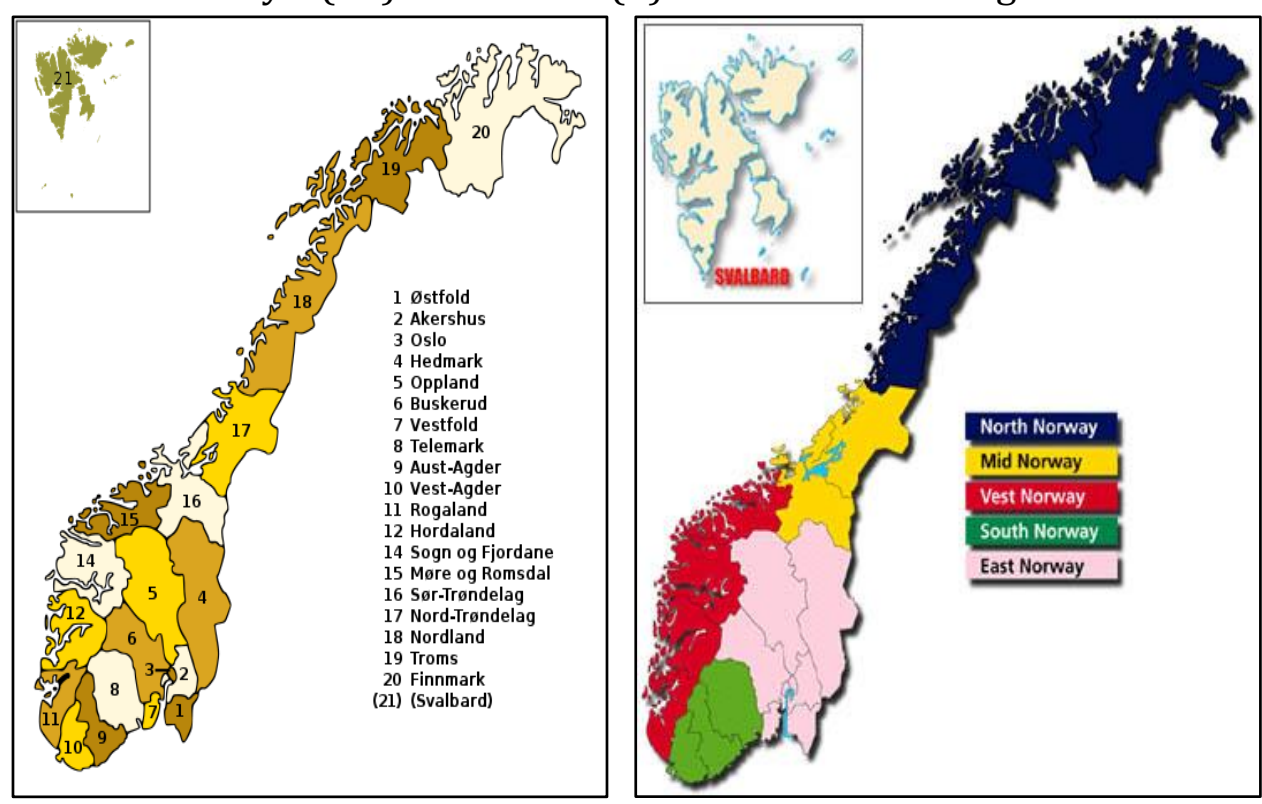

Source: Wikipedia

Source: www.gonorway.no

\subsubsection{UiT: the knowledge hub for the 'High North'}

Founded in 1968, the University of Troms $\varnothing$ (UiT) was the result of the interface between regionalization policy and higher education policy. The rationale for establishing a comprehensive university above the Arctic Circle was the need to promote socio- 
economic development, by providing the region with adequate skills and competences (medical doctors, teachers, lawyers, etc.) as well as knowledge, to enhance local absorptive capacity. UiT is the fourth largest university (out of eight, all public) in Norway. It is also the most northern university in the world. In 2014, it enrolled more than 12000 students and employed close to 3000 employees, 56\% of whom were directly involved in teaching and research activities. UiT's strategy . refers to the the university as a "knowledge engine" (Kunskapsmotor) for the High-North.

Figure 4: The High North Area

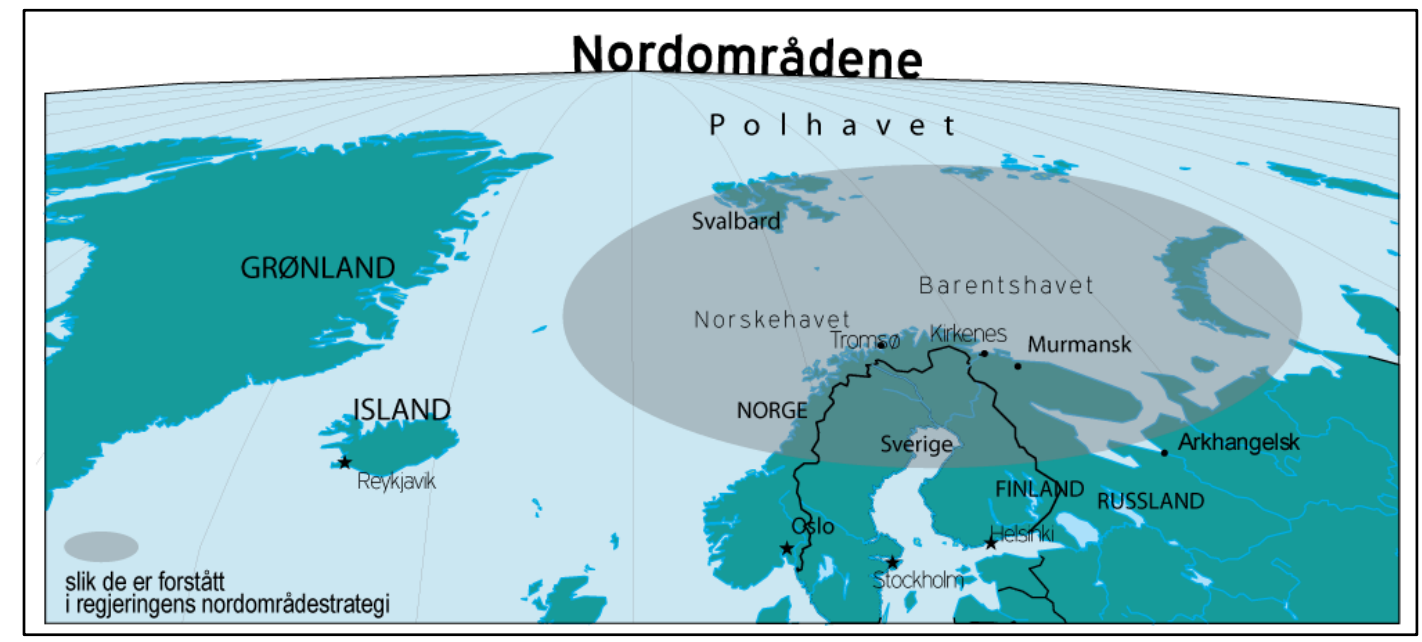

Source: NUPI

The strategy makes reference to active collaborations with the public and private sectors, and underscores UiT's responsibility for producing graduates with the relevant skills and competencies for local and national labour markets. An emphasis is given to sectors of the economy linked to the provision of welfare services; health, education, and culture. When it comes to industrial growth and innovation, UiT's strategy highlights the importance of graduates across the natural sciences (oil/energy sectors, bio-tech), technology (new media, ICT), and economics. A special mention is made of UiT's willingness to collaborate with other knowledge-based institutions located in the region as to better address local demands and expectations.

\subsubsection{Situated learning: the case of community medicine}

In the light of its original vision of becoming a different - more responsive and innovative - university, medicine academics at UiT decided to embark on a number of innovative practices and structures, some of which have turned out to be rather successful over the years. ${ }^{1}$ On the teaching front, these included: student internships at

${ }^{1}$ UiT's first appointed rector, Peter F. Hjort, has been characterised as an 'enterprising rector' (Arbo and Eskelinen 2003). Before taking the job, Hjort, a respected professor of medicine from Oslo, demanded a guarantee from the government that it would back a 
hospitals located in rural areas, as an integral component of university education; and, joint teaching activities for future medical doctors and nurses. In the research realm, the field of community medicine was then identified as an area of potential benefit for both the region and UiT's scientific profile, nationally and internationally. When compared to other parts of the country, Northern Norway possessed a higher incidence of certain type of health-related problems such as cardio-vascular diseases. ${ }^{2}$ Starting in the mid70 s, a group of health scholars decided to undertake a series of mostly quantitative studies on the topic, what became known as 'the Trømso study'. The latter aimed at determining the reasons for the high mortality associated with cardiovascular disease and to develop ways of preventing heart attacks and strokes. The study was gradually expanded to include many other diseases - rheumatism, neurological and mental diseases, skin diseases, stomach and bowel-related diseases, cancer and osteoporosis, etc. - and repeated at regular intervals, involving a large proportion of the local population (table 1).

Table 1: 'The Tromso Heart' Study (1974-2008)

\begin{tabular}{|c|c|c|c|c|}
\hline $\begin{array}{l}\text { Study } \\
\text { year }\end{array}$ & $\begin{array}{l}\text { Study's } \\
\text { name }\end{array}$ & $\begin{array}{l}\text { Number of } \\
\text { participants }\end{array}$ & $\begin{array}{l}\text { Response } \\
\text { rate }\end{array}$ & $\begin{array}{l}\text { Age } \\
\text { group }\end{array}$ \\
\hline 1974 & $\underline{\text { Troms } \varnothing 1}$ & 6,595 - men only & $74 \%$ & $20-49$ \\
\hline $1979-80$ & $\underline{\text { Troms } \varnothing 2}$ & $\begin{array}{l}16,621 \text { - men \& } \\
\text { women }\end{array}$ & $78 \%$ & $20-54$ \\
\hline 1986-87 & $\underline{\text { Troms } \emptyset} 3$ & $\begin{array}{l}21,826 \text { - men \& } \\
\text { women }\end{array}$ & $76 \%$ & $12-67$ \\
\hline 1994-95 & $\underline{\text { Troms } \emptyset 4}$ & $\begin{array}{l}27,158 \text { - men \& } \\
\text { women }\end{array}$ & $73 \%$ & $25-97$ \\
\hline 2001-02 & $\underline{\text { Troms } \varnothing 5}$ & $\begin{array}{l}8,130 \text { men and } \\
\text { women }\end{array}$ & $79 \%$ & $30-89$ \\
\hline $2007-8$ & $\underline{\text { Troms } \emptyset 6}$ & $\begin{array}{l}12,984 \text { men and } \\
\text { women }\end{array}$ & $66 \%$ & $30-87$ \\
\hline
\end{tabular}

Source: UiT

Over the years, the study became an international reference within the field, catapulting the rather small academic milieu of community medicine at UiT to the forefront of scientific developments on a global scale. In 1977 the Troms $\varnothing$ Study became Norway's most frequently referred scientific publication within the field of medicine. In the last three decades or so, the study has been refereed in more than 1,100 occasions in the specialist medical literature. A particular strength of the Tromsø Study is that it has

rapid build-up of the university including a fully integrated medical school and a university hospital.

\footnotetext{
${ }^{2}$ In the mid-1970s, $20 \%$ of Norwegian men died of myocardial infarction before the age of 75, while the situation in Northern Norway was even bleaker.
}

13 
made it possible to regularly study the development of risk factors for diseases among the same group of individuals during a period of more than three decades. A key success ingredient has been the high levels of participation - more than three quarters of those invited agreed to participate - by the local community (table 1), ensuring both quality and impact. ${ }^{3}$

Somewhat remarkably, the studies occurred in the absence of a long-term publicly funded programme, by either the regional or national authorities, with UiT's academics being the ones responsible for initiating the process and securing its long-term financial sustainability. External dynamics did play a key role nonetheless. In the early 80s, professional bodies like the American Public Health Association, the Polar Research Board of the US National Academy of Science, together with a number of other international groups, participated in a series of discussions on 'Arctic health research'. Combined with the early success and visibility of the Tromso study, such high level initiatives provided the adequate legitimacy for the establishment, in 1973, of a major community-health institute at UiT dedicated to 'health in the Arctic'. Today, the department of community-medicine employs more than 100 staff (37 professors and associate professors), half of whom are attached to externally-funded research projects, including about 40 PhDs. At the time of the inquiry (Spring 2014), the unit, one of seven departments at the faculty of health sciences, was structured around 5 sections or specialities, and hosted a number of high profile research units such as the Centre for Sami Health Research and the National Centre of Rural Medicine.

\subsection{Twente, the Netherlands.}

\subsubsection{The regional context ${ }^{4}$}

The region of Twente is located on the eastern border of the Netherlands, within the province of Overijssel. Covering a surface area of a little over $1500 \mathrm{~km}^{2}$, and with around 620,000 residents, the region is comprised of 14 municipalities, with a clear distinction between core urban concentration around the cities of Enschede, Hengelo, and Almelo, and a rural hinterland. Located approximately $100 \mathrm{~km}$ to the north of the great rivers, the region is split by the Salland moraine hills. The very sandy and slightly rolling landscapes of Twente originally offered relatively unfertile lands for farming, and the region developed a farming economy from the $16^{\text {th }}$ century onwards with a high degree of interdependence between farmers, and economic diversification within households.

An important element of that diversification was in home weaving, and by the $19^{\text {th }}$ century, the region had developed a specialisation in farm-produced textiles. This was displaced by the rise of the textiles industry in Flanders and Tilburg. But following

\footnotetext{
${ }^{3}$ As of 2014 , data from the Troms $\varnothing$ Study has been used in approximately 50 doctoral theses and in approximately 425 scientific articles published in recognised scientific publications.

${ }^{4}$ This section draws extensively on the case study of the Twente region undertaken as part of the ESRC-funded project "Bringing Cambridge to Consett", and draws upon Benneworth \& Hospers (2007a, 2007b).
} 
Belgian independence in 1830, and domestic political unrest in the west, the newly crown King William invested heavily in building up his domestic textiles industry in the remote isolation of Twente. Textiles provided the motor for regional growth until the 1960s when global competition forced regional companies into a steady and eventually terminal decline. Since the 1970s, the Twente region has faced a continual struggle to reindustrialise and build a new knowledge economy. Despite policy-makers' best efforts, Twente continues to underperform the national average in terms of key employment, unemployment and knowledge economy variables.

Figure 5: The Twente Region

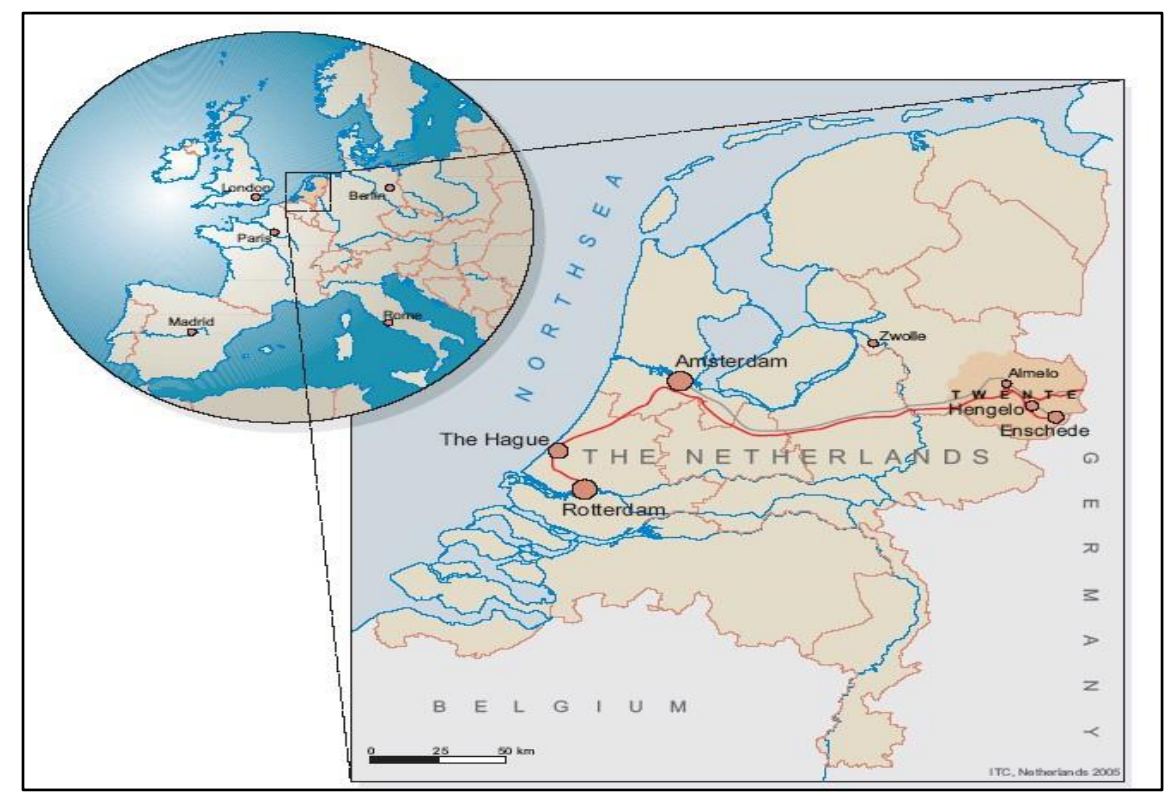

Source: ITC (2005) courtesy of Faculty ITC, University of Twente

\subsubsection{The University of Twente as a key knowledge economy actor}

An important element of policy-makers' response to the domestic economic crisis of Twente was the creation of a new university. From the post-war period, industrialists formed a Foundation 'for the promotion of technical higher education in the northern and eastern provinces of the Netherlands', to revitalise the region's declining industries. In the 1950s, this Foundation led a regional campaign for the newly announced third technical university for the Netherlands (after Delft and Eindhoven) to be located in Twente. Indeed Minister Cals announced in 1959 that the new Technische Hogeschool Twente (THT or Twente Technical College) would be located at Drienerlo, a country estate between the two main cities of Hengelo and Enschede. The university began its life in 1961 with the first students being admitted in 1964, but immediately entered a period of turmoil, with low student numbers and the steady decline of the industry it was supposed to support calling into question its continued viability. The university was established as an innovative and experimental institution that had to use an existing 
professoriat from the two technical universities in Delft and Eindhoven to create courses in entirely novel areas. The university survived largely by reinventing itself as a source of new growth for the region, working with regional policy-makers to develop new sectors and create new jobs, wealth and ultimately a new regional knowledge economy.

One part of its struggle for survival came in efforts to broaden its courses, and in particular, to create a medical faculty. Despite serious lobbying from within the region, the ninth Dutch medical faculty was awarded to the University of Maastricht. That institution was then in the process being created as part of a compensation package for the province of Limburg, at that time in crisis as a result of the closure of the nationalised mining industry. However, despite that initial failure, the University of Twente has placed considerable efforts into positioning itself to be a suitable candidate for a medical faculty. The university's strategy has been using its existing base as a university with several expertises in applied technology, drawing on its linkages with regional partners, to develop new specialisations.

\subsubsection{Situated learning: the case of technical medicine}

Two key regional partners for the university in developing this situated expertise were two regional hospitals, ' $t$ Roessingh specialist rehabilitation hospital and the generalist Medische Spectrum Twente (MST) hospital. Close links were created between the university and 't Roessingh starting in 1984, when the research director of ' $t$ Roessingh was granted a professorship at the university; in 1993, ' $t$ Roessingh formed its own R\&D centre ('t Roessingh R\&D, RRD) with close links to the university around rehabilitative medicine, complementing the university's expertise in device technology. Likewise, the university developed linkages with the MST Trust, with the perhaps overambitious hope to become a University Medical Centre Twente were it ever to be awarded medical degree-awarding powers. Its specialists were able to hold chairs at UT to carry out their medical research and develop their careers.

Those developments formed the basis for the launch of the Technical Medicine degree in 2003, approved by the Ministry of Education, technically split between two three year phases (bachelor-masters) but in practice handled as a single course (QANU, 2011). The pedagogical basis for this course is in training medical technicians with highereducation based competencies to carry out a number of specific medical technological interventions and procedures. The higher education based nature of the course means that the student is trained as a research professional with the capacity to improve and innovate in those areas, and there is the opportunity to progress at the end of the Masters' course into Ph.D. positions. The course handbook describes itself as creating a new kind of professional, the Technical Physician, "a new academic professional who has the knowledge, skills and problem solving mind-set to design and safely apply improved diagnostics and therapeutics for the benefit of patients"5. In 2011, the Dutch Quality Assurance Agency for Higher Education (QANU) accredited the Technical Medicine

\footnotetext{
${ }^{5}$ http://www.utwente.nl/tg/index2/
} 
programme and found that it was satisfactory or good in every dimension of education quality. In 2013, the course was taken up in the national Individual Health Care Professionals act (Wet BIG), which means that its graduates have the rights reserved to physicians to treat patients independently and perform procedures ${ }^{6}$.

This new capacity draws heavily on the regional partnership built up since the 1980s and embedded within key university teaching and research activities. An important element underpinning the creation of this new course was its location within a rich research environment. This research environment - supervising students and Ph.D.s - is currently provided by the MIRA research institute (formerly the Biomedical Technology Institute, or BMTI). BMTI was created by the university in 1992 as one of its four (then) leading technological institutes, bringing together a range of research fields to better profile them. BMTI (later MIRA) provided an institutional framework to host clinical professors from MST and RRD, in return for providing them with career opportunities comparable to their colleagues in University Medical Centres. These attached professors in turn provided UT with the medical expertise to put together and ultimately win a bid for this new course, and all graduating students participate in research projects overseen by research professors within considerable clinical medical expertise.

As part of the wider collaboration between the university and regional medical institutions around technical medicine, UT opened in 2011 the Experimental Centre for Technical Medicine ${ }^{7}$ (ECTM). Part of the rationale for ECTM was to createan on-campus training centre where students can learn how to use the various technologies necessary for their course. At the same time, those facilities were used by local hospitals in terms of the continuing professional development of their staff, for example in the use of new technological interventions in Intensive Care and Emergency Room settings. Finally, the ECTM offered a research infrastructure facility for the beta testing of new technological medical interventions by research companies as well as supporting the research activities of technical medical researchers attached to MIRA.

\section{The reality of universities and regional upgrading in the northern periphery}

In preparing this working paper as a chapter on a book on regional economic development and upgrading in the southern European periphery, we are interested in understanding how regions and universities can work together to steer university internal processes in order to better couple regional engagement activities - of whatever kind - to key university structures. Our two cases have illustrated that this coupling

\footnotetext{
${ }^{6}$ http://www.utwente.nl/en/archive/2013/11/technical-physicians-of-the-university-of-twente-included-inthe-individual-health-care-professions-act/

${ }^{7}$ http://www.technischweekblad.nl/opereren-op-poppen.127605.lynkx

17
} 
may happen when there is mutual beneficiality for universities and their surrounding localities in the context of regional upgrading strategies. We contend that this finding is not strongly contextual dependent, and because it relates to the ways that universities function as self-governing and loosely-coupled communities, these lessons have a wider applicability beyond Norway and the Netherlands and in particular for the southern periphery, the topic of this volume. In order to explicate these lessons more clearly, we recall the three elements set out above, namely:

(i) how these micro-learning communities were institutionalised and embedded in universities and regions;

(ii) the tensions they faced, and the barriers they overcame; and

(iii) the effect that this ultimately had on regional upgrading.

\subsection{Institutionalising micro-learning communities}

The first issue relates to what universities can do to institutionalise and embed these new micro-learning communities. In both cases, what has proven important is in generating successes that are recognised as such by universities' wider stakeholder communities, and by which universities feel themselves to be validated by these regional activities. In both these cases there was a 'stickiness' to the region that held these coalitions together over long-term periods necessary to build up these courses, and to address the emerging problems and tensions.

In the case of UiT, community medicine was an important element of the university being able to demonstrate to the Ministry of Health and the Norwegian parliament that it was an 'excellent research university' and deserved the funding brought by that status. In turn, these accomplishments contributed to enhance UiT's internal and external legitimacies, securing needed moral and financial support by key internal (university and organizational field) and external (government and society) stakeholders. The legitimization process was not only as regards knowledge production per se, but in embedding the generated knowledge within a specific knowledge (community medicine) and local (Northern Norway) community. It is indeed the case that that knowledge community was, in turn, rooted in regional specificities, but, more importantly, and in line of our non-contextual sensitive argument exposed above,this knowledge community became actively engaged in creating and transferring fundamental (universal) knowledge. This legitimises the activity as more than applied or 'mode-2' knowledge production geared towards local relevance, and, instead, emphasises how, in essence, it was a regionally-contextualised, globally excellent activity (consult Perry and May, 2006).

In Twente, the micro-institutionalisation of the learning community came by integrating a novel theme into the existing structure of the university. The failure to award the ninth medical faculty to Enschede was also a problem for regional medical institutions as they did not have a ready stream of new graduates to work in the emerging innovative fields, thereby threatening their own vitality. In the context of a university at 
the time searching for ways to validate itself as being both excellent and relevant, the presence of two other local knowledge institutions created an opportunity which was subsequently enthusiastically embraced. The presence of a regional critical mass around a particular theme - especially one which carried such a clear emotional resonance with some staff members - allowed the new activities to be constructed with limited internal resistance.

\subsection{Overcoming tensions and barriers}

The second issue in upgrading is addressing the tensions that arise when universities develop connections with their regions; effective university-region interaction requires that universities gain clear benefits for their core processes (e.g. teaching or research) from that engagement activity, whilst there are also clear value-added benefits for a wide set of regional stakeholders. Although the nature of the regional benefits will vary substantially with regional context, thereby inhibiting drawing sensible lessons for the southern periphery, it is clear there were similarities in the ways that the two universities were able to create obvious and demonstrable benefits through these regional learning community activities. The key issue has been in ensuring that the regional embedded learning continues to deliver benefits for the university over a long time period, as the nature of the activity evolves from being marginal to a more central part of the institution.

In Tromsø, tensions and dilemmas were largely associated with the lack of long term financial support for pursuing the academic agenda associated with the Troms $\varnothing$ study. These were, to a large degree, solved by the pro-active effort of (some) entrepreneurial academics that went to great lengths to secure vital internal and external financial support, thus guaranteeing the sustainability of the project. Another aspect relates to finding a balance between (global) scientific excellence and local relevance, accomplished in the form of efficient knowledge diffusion and direct participation in policy making process by some of the university actors. By clearly demonstrating the value of the knowledge generated in the Troms $\emptyset$ studies, for the university, the region, governmental authorities and for other knowledge production institutions as well (organisational field),, academics involved with community medicine were able to achieve vital internal and external support.

In UT the benefit was building a necessary critical mass around teaching and research to achieve accreditation and thereby allow a self-sustaining community to take root within the university. The solution taken was to first build up a university research strength in biomedicine as a natural iteration of existing strengths in technology fields (chemical engineering, sensors, telematics). The Biomedical Technological Institute provided a shared infrastructure for the diverse activities then spread across the existing faculties. This was also helped by a decision in 2000 by the University Board to give the 'spear point' research centres equivalence with faculties, allowing focus and investment to 
build up research excellence from which education later emerged, firstly as a speciality Biomedical Engineering masters, and latterly the accredited technical medicine course.

\subsection{Net effects on regional upgrading}

The final important element of the model (figure 1) relates to regional upgrading, and not merely creating a locally embedded university community, but in how that local community experience benefits in terms of its wider innovativeness, competitiveness and quality of life.

In both our case universities, these embedded knowledge communities, rooted in regional particularities mediated through the university became important nodes within wider knowledge circulation and valorisation networks, and ultimately global value chains as well. This, in turn, legitimated the activities within the regions, by avoiding any potential criticisms that the universities were merely 'cathedrals in the desert'. In both cases, these shared knowledge communities have been acknowledged by key external stakeholders as being of national economic significance, and helping two peripheral regions to bring themselves to the attention of policy-makers all too easily beguiled by the charms of the nearby, and familiar, (Oslo and Randstad) core regions.

UiT has had a number of effects around common areas of interests and developing knowledge relevant to the challenges of Arctic life, helping to raise regional productivity and the attractiveness of the region as a place of residence, as well as supportive policies and strategies in developing those strengths. Its international profile has helped other regional partners to have profiled themselves as being in a dynamic, rather than a backward, region, and therefore worthy of support for their knowledge and innovation activities. Additionally, health-related innovations have helped fuelled interest towards health-related issues like telemedicine. These efforts, combined with UiT's proven expertise within the natural sciences (fishery sciences included) have become the foundation for the rise of a set of regional knowledge-intensive marine biotechnology activities (Karlsen, Isaksen, \& Spilling, 2011). The value for the region has, therefore, been in finding a way to see the university as helping to create future opportunities for the region, in revitalise a declining industry and enable future job and growth opportunities.

The regional upgrading effects of UT have formed part of a wider process in Twente involving the creation of a series of anchors for embedded knowledge communities supported by the university, local and regional governance structures and also business. These embedded knowledge communities are not merely located in and around the university, but have also become embedded in other regional actors, and influential in their own formal organisations and informal cultures. There is a strategic co-operation between the university, the local municipality and region ('Kennispark') that has been active in investment towards research activities of mutual interest; at the same time, Kennispark is visible as a public-private partnership to government investors as an ideal type of knowledge valorisation space. This is something that has been very important to 
local stakeholders in being able to legitimate UT's activities as being value to them, and ultimately has led to this partnership to adopt a target of creating 10,000 new hightechnology jobs by 2020 .

\section{Lessons for university-regional engagement in southern Europe}

Regional upgrading processes (cf. Cooke \& Piccaluga, 2012) necessarily encompass a number of critical aspects far beyond this chapter's limited scope, although knowledge structures and university activities clearly contribute to regional upgrading by fostering regional collaboration and situated learning (Gertner et al., 2012). In this final section, we seek to draw some more general lessons that can be applied in the southern European periphery in those circumstances where universities seeking to create and exploit contextualised knowledge are restricted in doing so by institutional counterpressures, which we here refer to by the short-hand of being more 'globally excellent'. Under these circumstances, partners should be aware of the need to permit universities to book these successes as a necessary precondition of the parallel production of the contextualised knowledge.

The first is that knowledge need allow the university to legitimate itself in its own national political economy as a legitimate (research-intensive) university, and not find its role unnecessarily prescribed to being that as a regionally-relevant institution (Pinheiro et al., 2012) . This transcends mere institutional pride - all knowledge is created somewhere, and universities that can achieve wider recognition and validation for their locally-created knowledge will ceteris paribus also have a greater local impact (Feldman \& Desrochers, 2003). Troms $\emptyset$ was able to position itself as a knowledge hub for the 'High North', but that in turn allowed it to demonstrate its significance to a government at times often blinkered towards seeing Oslo, Bergen and the National Technical University at Trondheim (NTNU) as the extent of the Norwegian university system. In Twente, the validity of commercial activities was partly related to the fact that they were research-intensive and were validated externally in different ways including national research evaluations, international peer reviewed publications and, in part due to their capacity to win excellence-based research funding (cf. Kwiek, 2012).

A second element worth referring to is the role of certain academics who have been active in ensuring the structural changes necessary before contextual learning can be embraced within the university. We here distinguish three layers - firstly are those academics who are actively engaged with regional partners in creating new regionallycontextualised learning activities and thereby creating assets of value to the regional community, akin to what Shattock (2009) calls 'academic intrapreneurs'. But two other groups are also important within the university, and their scope for action and wider support dictates the extent to which they can fulfil this mission. The first are the university senior managers, who are critical in terms of depicting regional engagement 
activities as a core mission for the university, and at the same time being insistent upon their conformance with wider academic norms of excellence and universality. The second are academic peers, not themselves active within creating contextualised knowledge, but instead active within university teaching, research, promotions and resources committees: their willingness to lend these contextualised learning activities the imprimatur of legitimacy also helps to shape academic intrapreneurs' span of control.

We acknowledge that the case universities - both in Norway and the Netherlands - are embedded in national policy contexts where a privileged emphasis is placed on an active societal role, conditions that are not necessarily present in southern peripheries (Benneworth \& Hospers, 2007). In terms of drawing general lessons from our inquiry, we argue that universities' capacities to undertake societal activities is shaped by these national regulatory conditions; although in Twente, for example, the university was active as an entrepreneur university before the legal changes were made that 'permitted' that approach. To make it clear, we are not arguing that the national institutional frameworks per se (funding allocations included) dictate university activities, but where universities have an encouraging and institutionalised regulatory framework, as is the case of the Nordics and the Netherlands, they are freed from continually renegotiating their social missions and resource pools, thus ensuring them a certain degree of continuity and manoeuvrability (for the case of the Nordics consult Gornitzka and Maassen, 2011). Even, or perhaps particularly, where these national conditions are not so supportive, as is the case of some Southern European countries ( $c f$. Neave \& Amaral, 2011), then regional partners can support universities to create more contextualised knowledge activities and structures by appreciating that sometimes universities need to portray themselves in particular ways to central stakeholders that can lead them to appear regionally sensitive. If regional partners then accuse those institutions of being regional insensitivity, it further undermines the validity of external engagement, and therefore directly works counter to what those regional partners could potentially achieve otherwise.

\section{Bibliography}

Amin, A. and Roberts, J. (2008). Knowing in Action: Beyond Communities of Practice. Research Policy, 37 (2), 353-369.

Becher, T \& Trowler, P. R. (2001). Academic Tribes and Territories Intellectual enquiry and the culture of disciplines. Buckingham: The Society for Research into Higher Education \& Open University Press.

Bender, T. (1988) (ed.). The University and the City. From Medieval Origins to the Present. New York/Oxford: Oxford University Press.

Benner, C. (2003), Learning Communities in a Learning Region: The Soft Infrastructure of Cross Firm Learning Networks in Silicon Valley. Environment \& Planning A, 35(10), 1809-1830.

Benneworth, P. \& Osborne, M. (2014). Knowledge, engagement, and higher education in Europe. In R. Tandon \& B. Hall (Eds), Higher Education in the World 5: Knowledge engagement and higher education: contributing to social change (pp. 219-231) London: Palgrave Macmillan. 
Benneworth, P. (2013). The Engaged University in Practice? In P. Benneworth (Ed.), University engagement with socially excluded communities (pp. 329-343). Dordrecht: Springer.

Benneworth, P. S. \& Hospers, G.-J. (2007). Urban competitiveness in the knowledge economy: Universities as new planning animateurs. Progress in planning, 67(2), 99-198.

Bergek, A., S. Jacobsson, B. Carlsson, S. Lindmark, A. Rickne (2008). Analyzing the functional dynamics of technological innovation systems: A scheme of analysis. Research Policy, 37(3), 407-429

CERI (1982). The university and the community: the problems of changing relationships. Paris: OECD publishing.

Charles, D. \& Wilson. B. (2012) Managing Regional Engagement: The Role of Benchmarking. In R. Pinheiro, P. Benneworth \& Jones, G.A (eds.), Universities and Regional Development: A Critical Assessment of Tensions and Contradictions (pp. 219-238). Milton Park and New York: Routledge.

Charles, D. R. \& Benneworth, P. (2001). The regional contribution of higher education. London: HEFCE/ Universities UK.

Christopherson, S. \& Clark, J. (2007). Power in firm networks: what it means for regional innovation systems, Regional Studies, 41(9), 1223-1236.

Collini, S. (2012). What are universities for? London: Penguin.

Cooke, P. (2005). Regionally asymmetric knowledge capabilities and open innovation: exploring 'Globalisation 2' - a new model of industry organisation. Research Policy, 34, 1128-1149.

Cooke, P., \& Piccaluga, A. (2012). Regional Development in the Knowledge Economy. Milton Park and New York: Routledge.

Gertner, D., Roberts, J., \& Charles, D. (2011).University-industry collaboration: a CoPs approach to KTPs. Journal of Knowledge Management, 15(4),625 - 647.

Goddard, J. \& Vallance, P. (2013). The university and the city. London: Routledge.

Goddard, J. (2011). Connecting universities to regional growth: a practical guide. Brussels: DG REGIO.

Gornitzka, Å., \& Maassen, P. (2011). University governance reforms, global scripts and the "Nordic Model". Accounting for policy change? . In J. Schmid, K. Amos \& A. T. J. Schrader (Eds.), Welten der Bildung? Vergleichende Analysen von Bildungspolitik und Bildungssystemen (pp. 149-177). Baden-Baden: Nomos Verlagsgesellschaft.

Gunasekara, C. (2006). The generative and developmental roles of universities in regional innovation systems. Science and Public Policy, 33(2), 137-150. doi: $10.3152 / 147154306781779118$

Hansson, F. Husted, K. \& Vestergaard, J. (2004). Rethinking science parks - from structural holes jockeys to social capital catalysts, Technovation, 25 (10), 1039-1049.

Hassink, R. (2005). How to unlock regional economies from path dependency? From learning region to learning cluster.European Planning Studies, 13(4), 521-535.

Hermannsson, K, Lisenkova, K, McGregor, P , \& Swales, J (2013). The expenditure impacts of individual higher education institutions and their students on the Scottish economy under a regional government budget constraint: homogeneity or heterogeneity? Environment and Planning A, 45(3), 710 - 727.

Hospers, G.. (2006) Silicon Somewhere? Assessing the usefulness of best practices in regional policy. Policy studies, 270, 1-15.

Kallio, A,. Harmaakorpi, V. \& Pihkala, T. (2010).Absorptive Capacity and Social Capital in Regional Innovation Systems: The Case of the Lahti Region in Finland. Urban Studies, 47 (2), $303-319$.

Karlsen, J. E., \& Pritchard, R. (Eds.). (2013). Resilient Universities: Confronting Changes in a Challenging World. Oxford: Peter Lang. 
Karlsen, J., Isaksen, A., \& Spilling, O.(2011). The challenge of constructing regional advantages in peripheral areas: The case of marine biotechnology in Tromsø, Norway. Entrepreneurship \& Regional Development, 23(3-4), 235-257. doi: 10.1080/08985620903233945

Kickert, W. (1995). Steering at a Distance: A New Paradigm of Public Governance in Dutch Higher Education. Governance, 8 (1), 135-157.

Kwiek, M. (2012). Changing higher education policies: From the deinstitutionalization to the reinstitutionalization of the research mission in Polish universities. Science and Public Policy, 39(5), 641-654. doi: 10.1093/scipol/scs042

Lagendijk, A. \& Oinas, P. (2005). Proximity, Distance and Diversity, Issues on Economic Interaction and Local Development. London: Ashgate.

McCann, P., \& Ortega-Argilés, R. (2013). Smart Specialization, Regional Growth and Applications to European Union Cohesion Policy. Regional Studies, Vol. 49, No. 8, 1291-1302

Morgan, K. (1992). Innovating by networking - new models of corporate and regional development. In M. Dunford \& G. Kaflakas (Eds), Cities and Regions in the New Europe. (150169) London: Belhaven.

Morgan, K. \& Nauwelaers, C. (2002) (eds.) Regional innovation strategies: the challenge for lessfavoured regions. Routledge.

Mutch, A. (2003). 'Communities of practice and habitus: a critique.. Organization Studies, 24(3), 383-401.

Neave, G., \& Amaral, A. (2011). Higher education in Portugal 1974-2009: a nation, a generation. Dordrecht: Springer.

OECD (2007). Higher education and regions: globally competitive, regionally engaged. Paris: OECD Publishing.

Olsen, J. P. (2007). The institutional dynamics of the European university in P. Maassen and J. P. Olsen (eds.), University Dynamics and European Integration, (pp. 25-54). Dordrecht: Springer.

Perry, B. (2012). Excellence, Relevance and the Construction of Regional Science Policy: Science Frictions and Fictions in the North West of England. In R. Pinheiro, P. Benneworth \& G. A. Jones (Eds.), Universities and Regional Development: A critical assessment of tensions and contradictions, (pp. 105-123). Milton Park \& New York: Routledge.

Perry, B., \& May, T. (2006). Excellence, Relevance and the University: The "Missing Middle" in Socio-Economic Engagement. Journal of Higher Education in Africa, 4(3), 69-92.

Pinheiro, R. (2012a). Knowledge and the 'Europe of the Regions': The case of the High North. In Kwiek, M. and Maassen, P. (Eds.). National Higher Education Reforms in a European Context: Comparative Reflections on Poland and Norway (pp. 179-208), Frankfurt: Peter Lang.

Pinheiro, R. (2012b). University ambiguity and institutionalization: A tale of three regions. In R. Pinheiro, P. Benneworth \& G. A. Jones (Eds.), Universities and regional development: A critical assessment of tensions and contradictions (pp. 35-55). Milton Park and New York: Routledge.

Pinheiro, R., Benneworth, P., \& Jones, G. A. (2012). Understanding regions and the institutionalization of universities. In R. Pinheiro, P. Benneworth \& G. A. Jones (Eds.), Universities and Regional Development: An Assessment of Tensions and Contradictions (pp. 11-32).. Milton Park and New York: Routledge London and New York: Routledge.

Pinheiro, R., Benneworth, P., \& Jones, G. A. (2015). Beyond the obvious: Tensions and volitions surrounding the contributions of universities to regional developmen. In L. Farinha, J. Ferreira, H. Lawton-Smith \& S. Bagchi-Sen (Eds.), Handbook of Research on Global Competitive Advantage through Innovation and Entrepreneurship (pp. 150-172). Hershey, PA: IGI.

QANU (2011) Technical medicine: faculteit technische wetenschappen, Utrecht, QANU, May 2011, Available online at: https://search.nvao.net/files/4f182c7078ae6_rapport\%20UTwente\%20woma\%20Technical\%20Medicine.pdf (Accessed 15th September 2015)

Reponen, T. (1999). Is leadership possible at loosely coupled organizations such as universities? Higher Education Policy, 12(3), 237-244. 
Roberts, J. (2014). Community and the Dynamics of Spatially Distributed Knowledge Production: The Case of Wikipedia.In R. Rutten, P., Benneworth, D. Irawati, \& F. Boekema(Eds), The social dynamics of innovation networks. London: Routledge (pp. 180-200)

Shattock, M. (2009). Entrepreneurialism in universities and the knowledge economy: diversification and organizational change in European higher education. London: SRHE \& Open University Press.

Sotarauta, M., Horlings, I., \& Liddle, J. (2012) (Eds), Leadership and change in sustainable regional development. London: Routledge.

van Vught, F.\& Westerheijden, D. (2010). Multidimensional ranking: a new transparency tool for higher education and research.Higher Education Management and Policy, 22(3),1-26. 
The Center for Higher Education Policy Studies (CHEPS) is a research institute (WHW, Article 9.20) located in the Faculty of Behavioural and Management Scienes within the University of Twente, a public university established by the Dutch government in 1961. CHEPS is a specialized higher education policy centre that combines basic and applied research with education, training and consultancy activities.

http://www.utwente.nl/bms/cheps/

$|c| h|l| p|s|$

Center for

Higher Education

E

Policy Studies 